\title{
Comprehensive Review of the Relative Clinical Utility of B-Type Natri- uretic Peptide and N-Terminal Pro-B-Type Natriuretic Peptide Assays in Cardiovascular Disease
}

\author{
Peter A. McCullough* and Ariane Neyou
}

\author{
Department of Medicine, Divisions of Cardiology, Nutrition and Preventive Medicine, William Beaumont Hospital, \\ Royal Oak, MI, USA
}

\begin{abstract}
Measurable B-type natriuretic peptides, which are largely produced by the left ventricle, include B-type natriuretic peptide (BNP) and N-terminal pro-B-type natriuretic peptide (NT-proBNP). These proteins are released by cardiomyocytes in response to wall-tension and neurohumoral signals. In this review the literature is summarized to date with respect to the approved indications for testing which include the diagnostic evaluation and prognosis of heart failure. PubMed in 2009 was searched and 5496 references were reduced to 242 studies that reported on either diagnosis, prognosis, screening, or monitoring of heart failure. In head-to-head diagnostic comparisons, 58 studies measured both assays, and 11 studies in adults that included at least 100 patients compared commercially available tests. We performed the analogous search in acute coronary syndromes (ACS) and found 82 articles of which 11 papers focused on the study of BNP and NT-proBNP in either stable angina, non-ST-segment elevation myocardial infarction or ST-segment elevation myocardial infarction. For heart failure diagnosis, BNP and NT-proBNP had similar decision statistics; however, while optimal diagnostic cutpoints for both markers varied depended on age and degree of renal dysfunction, and the clinical application; NT-proBNP had a much more widely variable optimal cutpoint than did BNP. Sufficient evidence for clinical utility of both tests exists for other applications of prognosis, screening, and monitoring of heart failure. In addition, both tests have a role in the risk stratification of all forms of ACS. Future trials of clinical strategies are warranted using these tools in advancing both inpatient and outpatient management of heart failure and ACS.
\end{abstract}

Keywords: B-type natriuretic peptide, N-terminal pro-B-type natriuretic peptide, heart failure, diagnosis, prognosis, systematic review, hospitalization, mortality.

\section{INTRODUCTION}

Recently it has been recognized and shown that tests for B-type natriuretic peptide and for the amino terminal fragment NT-proBNP are accurate and useful markers of heart failure (HF). These tests have been shown to improve physicians' ability to diagnose HF in symptomatic patients. Accurate diagnosis of HF without these markers has been difficult in the past, particularly in acutely ill patients, in part because symptoms such as dyspnea, fatigue, and edema are relatively non-specific [1-3]. These symptoms are also common in obese and elderly patients with a variety of medical problems and in those with respiratory disease, making diagnosis of HF more challenging [3]. Indeed, the accuracy of clinical assessment of HF by history, physical exam, and conventional testing alone has been fallible, particularly in female, elderly, and obese patients $[4,5]$.

BNP and NT-proBNP are invaluable tools for physicians to introduce early intervention and to manage patient care [68]. Annual costs of treating HF patients in the United States are estimated at $\$ 65$ billion, $70 \%$ of which is due to hospitalization. Half of HF patients are readmitted to the hospital within 6 months of discharge and $10 \%$ are readmitted twice

*Address correspondence to this author at the Divisions of Cardiology, Nutrition, and Preventive Medicine, William Beaumont Hospital, 4949 Coolidge Highway, Royal Oak, MI 48073, USA; Tel: 248-655-5948; Fax: 248-655-5901; E-mail: peteramccullough@gmail.com
[9]. Fewer readmissions by BNP or NT-proBNP guided therapy can significantly impact the costs associated with this prevalent disease.

BNP and NT-proBNP have been shown to be sensitive and accurate markers of HF and have been shown to be superior for predicting $\mathrm{HF}$ relative to other markers of cardiac dysfunction [10-17]. The gene for BNP is located on chromosome 1 (Fig. 1) and can be rapidly activated in response to signal transduction from the myocyte cell wall. After protein synthesis, BNP is cleaved from the precursor molecule, proBNP by corin into the active BNP hormone and the inactive NT-proBNP fragment. Biologically active BNP is released from cardiomyocytes in response to wall tension, which according to the law of Laplace, is determined by the pressure within and the radius of the chamber. Since the left ventricle has the greatest mass by far of all the cardiac chambers, these natriuretic peptides largely reflect the dynamic wall tension experienced by the left ventricle that occurs with pressure and volume overload and neurohumoral activation in heart failure $[11,18]$ with levels of these markers relating to the severity of HF symptoms and cardiac dysfunction [10,19-21]. In the setting of acute and chronic right ventricular pressure overload, both BNP and NT-proBNP can be elevated but not typically to the levels seen in left ventricular failure. All assays for BNP and NT-proBNP recognize epitopes on the parent peptide proBNP, thus, in the setting of acute decompensated heart failure, it is believed 


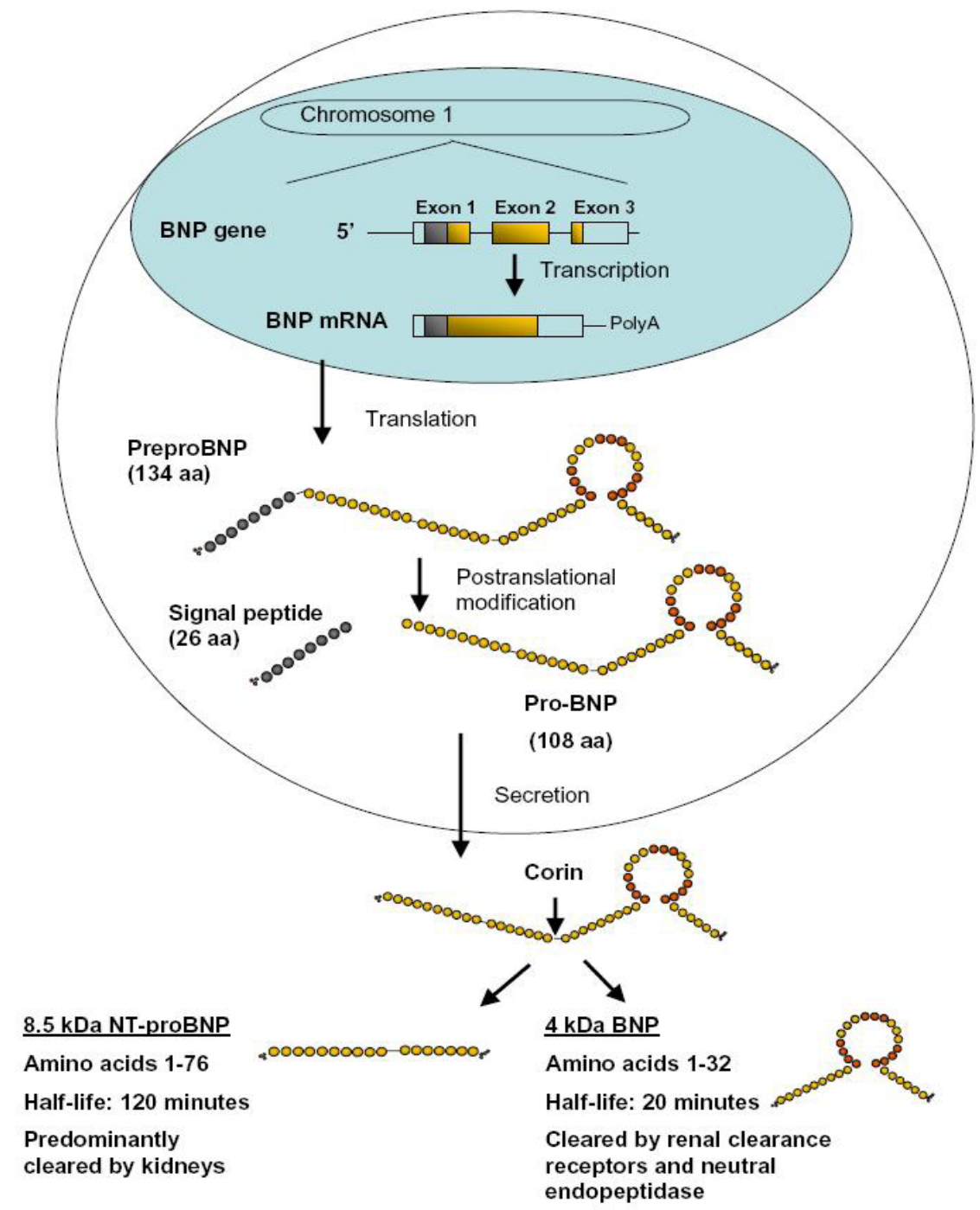

Fig. (1). Synthesis and secretion of natriuretic peptides from cardiomyocytes.

that levels of these proteins reflect both "immature" and mature peptide products [22]. In addition, fragment peptides are known to be in the circulation of patients with heart failure (BNP3-32 and BP6-32) and glycosylation of both BNP and NT-proBNP can occur as with many proteins to a variable degree depending on levels of glycemia and circulatory durations of the peptides $[23,24]$. Both BNP and NT-proBNP rise quickly in the setting decompensation and have sustained elevation provided increased wall tension and neurohumoral activation remain present [12-17].

There are some differences that may affect the relative usefulness of these two markers in different patient populations which will be discussed in this paper. For example, BNP has a shorter half-life than NT-proBNP because they are cleared by different mechanisms. Thus levels of NTproBNP are higher than those of BNP despite being produced at a theoretical 1:1 ratio. While the predominant pathway for clearance of NT-proBNP is by renal excretion, BNP appears to have a multiple clearance pathways including NP clearance receptors in the kidney and peripheral tissues as well as degradation by plasma neutral endopeptidase (vasculature), meprin A (kidneys), and neprilysin (brain) [25-27].
Thus, BNP levels are less affected by renal dysfunction alone than are levels of NT-proBNP [9, 28]. However levels of both peptides can be elevated in the setting of chronic kidney disease and loss of renal mass and this may give a misleading elevation of one or both suggests suggesting cardiac decompensation.

\section{METHODS}

The Pubmed database was searched in 2009 using the following terms: "Brain natriuretic peptide [text word] OR "Natriuretic Peptide, Brain"[MeSH Term] OR "pro-brain natriuretic peptide (1-76)" [MeSH Term] OR "B-type natriuretic peptide"[Text Word]. This search gave 5496 references and when searched within these terms for primary studies that investigated the analysis of these markers for the diagnosis, prognosis determination and treatment monitoring of HF patients, 242 references were found. This list was further reduced to include only studies that specifically tested the sensitivity, specificity and accuracy of these tests as primary means for determining diagnosis or prognosis in adult HF patients or those that directly compared the two assays (108 references, 58 of which were studies that compared the 


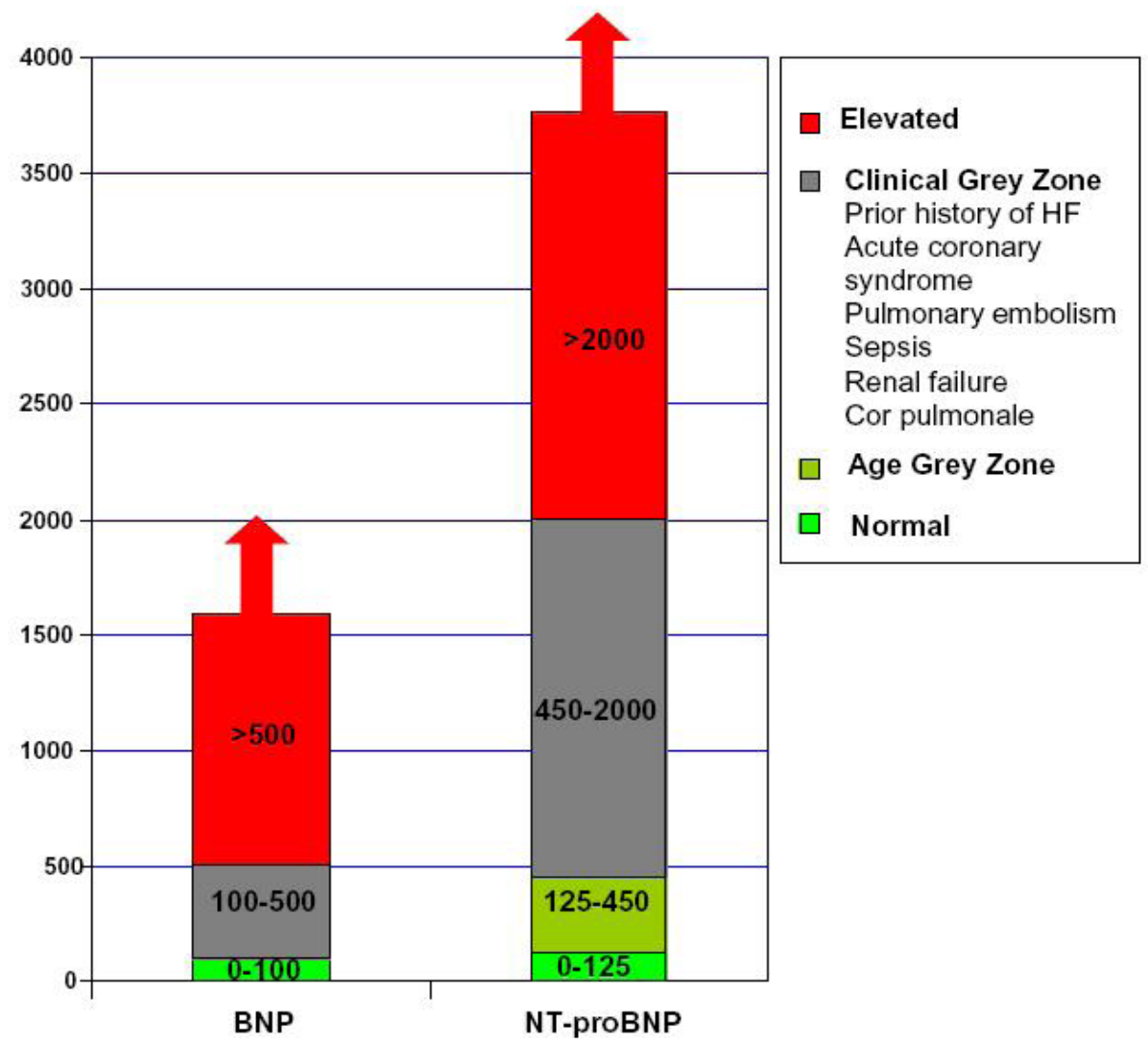

Fig. (2). Comparison of the diagnostic categories of BNP and NT-proBNP values as summarized in the clinical studies for the diagnosis of HF in symptomatic patients.

two assays). The yield was narrowed by excluding direct comparison studies that did not include measures of sensitivity, specificity and area under receiver operator characteristic curve and studies on pediatric patients, those with less than 100 patients and those using obsolete radioimmunoassays for BNP or NT-proBNP.

We performed the analogous search by using the terms BNP and acute coronary syndrome in the PubMed database and found 82 articles. Among those articles, we excluded all which were not focused or either BNP or NT-proBNP and ischemic heart disease, but also on other cardio biomarkers and heart failure. This search resulted in 11 articles that were focused only on the study of BNP and NT-proBNP in either stable angina, non-ST-segment elevation myocardial infarction or ST-segment elevation myocardial infarction.

\section{DIFFERENTIAL DIAGNOSIS IN PATIENTS WITH ACUTE DYSPNEA}

BNP and NT-proBNP levels are sensitive, specific and quantitative markers of HF [12, 17]. In general, more clinical data exists for BNP but both markers have been shown to be clinically useful in the diagnosis of HF in patients presenting with acute dyspnea in emergency departments (ED) and in determining the prognosis of HF patients [10, 29]. Testing for these markers is recommended by multiple heart failure guidelines including those from the European Society of

Table 1. Summary of Data from Studies that Examined BNP as a Diagnostic Aid in Symptomatic Patients with Suspected Heart Failure

\begin{tabular}{|c|c|c|c|c|c|c|c|c|c|}
\hline Size & Optimal Cutpoint & Sens & Spec & PPV & NPV & Acc & AUC & Assay & Reference \\
\hline 52 & $22 \mathrm{pg} / \mathrm{mL}$ & 93 & 90 & 87 & 95 & 91 & ND & Not stated in methods. & Davis [12] \\
\hline 250 & ND & 94 & 94 & 92 & 96 & 94 & 0.98 & TRIAGE (Biosite) & Dao et al. $[35]$ \\
\hline 1586 & $100 \mathrm{pg} / \mathrm{mL}$ & 90 & 76 & 77 & 90 & 84 & 0.90 & TRIAGE (Biosite) & Maisel et al. $[36]$ \\
\hline 70 & $200 \mathrm{pg} / \mathrm{mL}$ & 100 & 97 & 97 & 100 & 99 & ND & (Biosite) & Villacorta et al. [37] \\
\hline 308 & $250 \mathrm{pg} / \mathrm{mL}$ & 78 & 90 & 87 & 83 & 84 & 0.87 & TRIAGE (Biosite) & Ray et al. [38] \\
\hline
\end{tabular}

Abbreviations: Size, study size; Sens, sensitivity; Spec, specificity; PPV, positive predictive value; NPV, negative predictive value; Acc, accuracy; AUC, area under the receiver operating characteristic curve; ND, not determined in the study and not able to be determined by the data provided by the study. 
Table 2. Summary of Data from Studies Testing NTproBNP as a Diagnostic Aid in Suspected HF

\begin{tabular}{|c|c|c|c|c|c|c|c|c|c|}
\hline Size & Optimal Cutpoint $(\mathbf{p g} / \mathbf{m L})$ & Sens & Spec & PPV & NPV & Acc & AUC & Type assay & Reference \\
\hline \hline 100 & 115 & 93 & 90 & 98 & 74 & 92 & 0.96 & Elecsys (Roche) & Bayes-Genis et al. $[40]$ \\
\hline 122 & 1760 & 90 & 96 & 97 & 87 & 93 & 0.82 & Elecsys (Roche) & Zaninotto et al. [39] \\
\hline 1256 & $\begin{array}{c}450(<50 \mathrm{yrs}) \\
900(50-75 \mathrm{yrs}) \\
1800(>75 \mathrm{yrs})\end{array}$ & 90 & 85 & 78 & 99 & 87 & 0.94 & Elecsys (Roche) & Januzzi et al. [43] \\
\hline
\end{tabular}

Abbreviations: Size, study size; Sens, sensitivity; Spec, specificity; PPV, positive predictive value; NPV, negative predictive value; Acc, accuracy; AUC, area under the receiver operating characteristic curve.

Cardiology, the American College of Cardiology/American Heart Association and the National Academy of Biochemistry [30-33].

Using tests for BNP or NT-proBNP improves diagnosis of HF in patients presenting with acute dyspnea in the ED as demonstrated in several seminal studies (Tables 1 \& 2) [12, 34-41]. The use of optimal cutoff values allows physicians to quickly rule out or rule in HF as a cause of patient symptoms.

Multiple single center studies demonstrated the usefulness of BNP as a diagnostic tool in the ED [12, 34-41] and this was validated by the Breathing Not Properly (BNP) Multinational Study [42]. In this study, BNP was tested in a large $(\mathrm{N}=1586)$ multicenter, prospective, blinded, and adjudicated format, and it demonstrated that utilization of BNP testing lead to more accurate diagnoses than ED physician judgment based on patient history, physical findings, chest $\mathrm{x}$ ray, and other laboratory values [42]. In the BNP Multinational Study, the authors determined that the optimal cutoff values of $100 \mathrm{pg} / \mathrm{mL}$ yielded a sensitivity of $90 \%$ and a specificity of $76 \%$. A recent meta-analysis of the studies of the usefulness of BNP testing determined that testing for BNP was useful for improving accurate diagnosis of HF in ED patients presenting with acute dyspnea, particularly when the symptoms of HF were mild [29]. Multiple studies have shown that NT-proBNP is also highly useful in diagnosing dyspneic patients in the ED (Table 2) [39, 40]. The ProBNP Investigation of Dyspnea in the ED (PRIDE) study ( $\mathrm{N}=600)$ evaluated whether using NT-proBNP assay could enhance the accuracy of HF diagnoses in ED patients [43, 44]. NTproBNP at cutpoints of $>450 \mathrm{pg} / \mathrm{mL}$ for patients $<50$ years of age and $>900 \mathrm{pg} / \mathrm{mL}$ for patients $\geq 50$ years of age were highly sensitive and specific for the diagnosis of acute HF ( $p$ $<0.001$ ). Similar to the findings for BNP, this study concluded that awareness of patient NT-proBNP levels together with clinical judgment gave superior results than either method alone [43, 44]. Thus both markers appear to exhibit equivalent performance in diagnosing symptomatic patients. In addition, both BNP and NT-proBNP have been shown to be useful in diagnosing HF in symptomatic patients in other departments of the hospital and in symptomatic patients presenting to their general practitioners [45-47]. It is important to point out that elevation of one or both markers calls for a differential diagnosis to be constructed with includes decompensated heart failure, acute coronary ischemia, pulmonary embolism, cor pulmonale, sepsis, renal insufficiency, and in rare cases recurring arrhythmias.
Both tests have been shown to have a positive economic impact on the cost of patient care. In the BNP for Acute Shortness of Breath EvaLuation (BASEL) Trial, it was shown that utilization of BNP testing in the ED decreased the total time from initial presentation to initiation of treatment from 90 to 63 minutes. In addition, BNP results decreased the rate of admission from $85 \%$ to $75 \%$ and reduced the total costs of treatment in this patient population from $\$ 7264$ to $\$ 5310$ [48]. The IMPROVE-CHF study showed that NT-proBNP also could significantly decrease costs associated with patient care. Use of NT-proBNP testing reduced the duration of time spent in the ED by $21 \%$ and the rate of readmission by $35 \%$. Medical costs were reduced in the patient population analyzed from $\$ 6129$ to $\$ 5180$ over 60 days as a result of including the test in managing patient care [49].

NT-proBNP has a longer half-life in vivo than does BNP and it has been argued that because of this, it may be a more sensitive than BNP. However, several head-to-head comparisons have been done to compare BNP and NT-proBNP assays, and together these data suggest that they are generally equivalent in terms of sensitivity and specificity in the general population (Table 3). BNP and NT-proBNP assays vary in sensitivity and specificity depending upon the platform used, the patient population, and the diagnostic cutpoint used, which may all account for some of the heterogeneity in the data [50-53]. Three separate meta-analyses of data from clinical studies have been done on the body of work directly comparing the sensitivity and specificity these two assays for diagnosing HF patients $[50,54,55]$. Two of these analyses concluded that they are generally equivalent in their sensitivity in accurately diagnosing HF in symptomatic patients [50, 54]. Interestingly, one meta-analysis specifically addressed the functionality of these tests in different age groups and concluded that BNP is superior, particularly in older patients [54]. Thus, the longer half-life and higher measurable levels of NT-proBNP do not translate to superior sensitivity, and in fact BNP may have better accuracy in elderly patients and those with chronic kidney disease. Both peptides are elevated modestly in the setting of diastolic HF but not typically to the levels achieved in patients with decompensated systolic HF.

\section{RELATIVE VALUE OF BNP AND NT-PROBNP IN HEART FAILURE PROGNOSIS}

In addition to their usefulness in diagnosing HF in symptomatic patients, BNP and NT-proBNP are able to provide prognostic information and improve admission decisions in 
Table 3. Summary of Head-to-Head Studies which Compared the BNP and NTproBNP Assays as a Diagnostic Aid in Suspected Heart Failure Patients

\begin{tabular}{|c|c|c|c|c|c|c|c|c|c|c|c|c|c|c|c|c|}
\hline $\begin{array}{l}\text { BNP } \\
\text { Assay }\end{array}$ & $\begin{array}{l}\text { Optimal } \\
\text { Cutpoint } \\
(\mathbf{p g} / \mathrm{mL})\end{array}$ & Sens & Spec & PPV & NPV & Acc & AUC & $\begin{array}{c}\text { NTproBNP } \\
\text { Assay }\end{array}$ & $\begin{array}{c}\text { Optimal } \\
\text { Cutpoint } \\
(\mathbf{p g} / \mathrm{mL})\end{array}$ & Sens & Spec & PPV & NPV & Acc & AUC & Refs \\
\hline $\begin{array}{l}\text { TRIAGE } \\
\text { (Biosite) }\end{array}$ & 60 & 94 & 70 & 63 & 98 & 80 & 0.89 & $\begin{array}{l}\text { ECLIA } \\
\text { (Roche) }\end{array}$ & 340 & 80 & 87 & 76 & 89 & 84 & 0.89 & [120] \\
\hline $\begin{array}{l}\text { TRIAGE } \\
\text { (Biosite) }\end{array}$ & 150 & 94 & 61 & 60 & 94 & 73 & 0.82 & $\begin{array}{l}\text { ECLIA } \\
\text { (Roche) }\end{array}$ & 1000 & 97 & 63 & 61 & 97 & 77 & 0.84 & [121] \\
\hline $\begin{array}{l}\text { TRIAGE } \\
\text { (Biosite) }\end{array}$ & 250 & 73 & 91 & 86 & 81 & 83 & 0.85 & $\begin{array}{l}\text { ECLIA } \\
\text { (Roche) }\end{array}$ & 1500 & 75 & 76 & 71 & 80 & 76 & 0.80 & [122] \\
\hline $\begin{array}{l}\text { TRIAGE } \\
\text { (Biosite) }\end{array}$ & 290 & 76 & 88 & 73 & 89 & 84 & 0.84 & $\begin{array}{l}\text { ECLIA } \\
\text { (Roche) }\end{array}$ & 1360 & 77 & 86 & 71 & 90 & 83 & 0.85 & [123] \\
\hline $\begin{array}{c}\text { MEIA } \\
\text { (Abbott) }\end{array}$ & 295 & 80 & 86 & 87 & 78 & 83 & 0.92 & $\begin{array}{l}\text { ECLIA } \\
\text { (Roche) }\end{array}$ & 825 & 87 & 81 & 84 & 84 & 84 & 0.90 & [124] \\
\hline $\begin{array}{l}\text { ADVIA } \\
\text { (Bayer) }\end{array}$ & 79 & 95 & 96 & 95 & 96 & 96 & 0.98 & $\begin{array}{l}\text { ECLIA } \\
\text { (Roche) }\end{array}$ & 817 & 98 & 94 & 93 & 97 & 96 & 0.98 & [125] \\
\hline $\begin{array}{l}\text { ADVIA } \\
\text { (Bayer) }\end{array}$ & 21 & 81 & 72 & 49 & 92 & 74 & 0.84 & $\begin{array}{l}\text { ECLIA } \\
\text { (Roche) }\end{array}$ & 143 & 87 & 87 & 70 & 95 & 87 & 0.93 & [126] \\
\hline $\begin{array}{l}\text { ADVIA } \\
\text { (Bayer) }\end{array}$ & 35 & 69 & 49 & 82 & 68 & 84 & 0.60 & $\begin{array}{l}\text { ECLIA } \\
\text { (Roche) }\end{array}$ & 235 & 53 & 78 & 89 & 33 & 59 & 0.67 & [127] \\
\hline $\begin{array}{l}\text { TRIAGE } \\
\text { (Biosite) }\end{array}$ & 100 & 79 & 72 & 59 & 87 & 74 & 0.80 & $\begin{array}{l}\text { ECLIA } \\
\text { (Roche) }\end{array}$ & 125 & 98 & 35 & 35 & 97 & 57 & 0.85 & [128] \\
\hline
\end{tabular}

Abbreviations: Sens, sensitivity; Spec, specificity; PPV, positive predictive value; NPV, negative predictive value; Acc, accuracy; AUC, area under the receiver operating characteristic curve; Refs, references.

patients with diagnosed HF. In the context of patient care, it has been proposed that because of its shorter half-life in vivo, BNP may be more useful than NT-proBNP to track improvement following therapeutic intervention and in acute $\mathrm{HF}$ because it is more sensitive to rapid hemodynamic changes in response to treatment [56]. Several studies have tested the value of each marker in guiding patient care [49, 57-60].

Measurement of BNP levels has been shown to accurately identify high-risk chronic HF patients. In one study the authors found that patients with BNP levels above 350 $\mathrm{pg} / \mathrm{mL}$ were five times more likely to die or be readmitted for $\mathrm{HF}$ if discharged [61]. Patients with levels over 700 $\mathrm{pg} / \mathrm{mL}$ had 15 times the risk of death or readmission, which occurred in $90 \%$ of the patients in the study [61]. The BNP assay was able to predict adverse patient outcomes with an area under the ROC curve of 0.83 . In another study of 325 ED patients, BNP levels above $480 \mathrm{pg} / \mathrm{mL}$ could predict adverse outcomes with a sensitivity of $68 \%$ and a specificity of $88 \%$ and area under the ROC curve of 0.87 [62]. BNP assays have strong prognostic value in both elderly and diabetic patients $[63,64]$ and may be a stronger predictor in women compared to men [65].

NT-proBNP levels also correlate well with patient prognosis. Studies using multiple measurements of NT-proBNP in $\mathrm{HF}$ patients during treatment suggest that the absence of a decrease in levels during hospitalization correlates with mortality or readmission within 6 months of discharge [66-69]. In one study, the authors concluded that a reduction of less than $30 \%$ was predictive of death with area under the ROC curve 0.78 [70], while another concluded that using admis- sion levels of NT-proBNP of $>986 \mathrm{pg} / \mathrm{mL}$ could predict oneyear mortality with area under the ROC curve 0.76 [71]. Schou et al. determined that every time NT-proBNP doubled, the hazard ratio for death increased by $56 \%$ and that for readmission increased by $19 \%$ [72]. A PRIDE substudy showed that NT-proBNP was able to give valuable prognostic information in patients with diabetes [73].

Several studies have been done to directly compare the prognostic performance of BNP and NT-proBNP. One study compared these markers in chronic HF patients and did not find significant differences in their accuracy [74] while another found that NT-proBNP had increased prognostic power over BNP for all cause mortality in acute decompensated HF patients [75]. In accordance with the ability of these markers to provide prognostic information in HF patients, multiple studies have shown that they both may improve admission decisions in HF patients. Direct comparisons of the relative value of BNP and NT-proBNP to guide HF patient care have not been made. Several studies in CAD patients with no overt symptoms of HF suggest similarly that both markers provide valuable prognostic information in earlier disease states and that NT-proBNP may provide a slight advantage $[68,76,77]$.

\section{RELATIVE ADVANTAGES OF BNP AND NT- PROBNP IN DIFFERENT PATIENT POPULATIONS}

Several factors other than cardiac function affect levels of BNP and NT-proBNP including gender, age, BMI, renal disease, and certain pulmonary conditions [78-80]. Some of these factors can influence the accuracy of these assays for determining diagnosis and prognosis in HF patients. Levels 
of both BNP and NT-proBNP are elevated in certain types of pulmonary disease such as cor pulmonale, lung cancer, and pulmonary embolism [81-83]. Baseline levels of both BNP and NT-proBNP are lower in obese patients in normal patients and in those with heart failure [84-87]. This relationship appears to be independent of left ventricular function and hemodynamics. The mechanism by which levels of BNP and NT-proBNP are decreased in obese patients is poorly understood. NPR-C receptors are that bind BNP are expressed on adipose tissue. However the observation that both BNP and NT-proBNP are decreased in obese patients suggests that rather than enhanced clearance via NPR-C receptors, reduced production of BNP/NT-proBNP is responsible for the decreased levels observed in overweight patients [88]. In one study NT-proBNP levels fell below optimal cutoff values in $15 \%$ of obese patients with HF while BNP levels were falsely negative in $20 \%$ of obese patients, suggesting that NT-proBNP levels may be slightly less affected by BMI than BNP [89]. However it is clear that for both markers, BMI must be taken into account when interpreting results, particularly if levels are close to indicated cutoff values [9]. Race and gender may influence levels but do not negatively impact the usefulness of either marker in diagnosing $\mathrm{HF}$ in dyspneic subjects $[79,80]$.

BNP is more effective than NT-proBNP as an independent marker for HF in elderly patients, particularly in those with renal disease $(9,10,74)$. The Breathing Not Properly study showed a correlation between eGFR and BNP in patients with and without HF. Thus, patients with chronic kidney disease (CKD) do have elevated levels of BNP. However, if the cutpoint for BNP is increased by $200 \mathrm{pg} / \mathrm{mL}$, an acceptable area under the curve of 0.80 exists for BNP as a marker for HF in CKD patients [28]. Elevation of NTproBNP in contrast is much more accentuated in elderly patients and in those with renal disease in part because it is solely cleared by the kidneys. This elevation of NT-proBNP is so dramatic that the values may give false positives, and thus different cutoff values must be used $[9,31,32,90]$. In a PRIDE substudy, the authors found that using a cutpoint of $1200 \mathrm{pg} / \mathrm{mL}$ for patients with GFR $<60 \mathrm{~mL} / \mathrm{min} / 1.73 \mathrm{~m} 2$ gave an acceptable AUC of 0.88 , with sensitivity of $89 \%$ and a specificity of $72 \%$ [90]. This is one of the main differences that have been found between the two assays and may be a significant advantage of the BNP assay for diagnostic purposes because HF is most prevalent in elderly patients [9194]. In contrast, several studies have also shown that there is no difference in the correlation of BNP and NT-proBNP and the prognostic utility of these markers in patients with renal disease $[95,96]$.

In conclusion, both tests can accurately diagnose HF in elderly patients or in those with renal disease. However, a simpler diagnostic algorithm is associated with BNP results than NT-proBNP results for diagnostic purposes, which must take age and renal dysfunction into consideration when determining cutoff values.

\section{SCREENING ASYMPTOMATIC PATIENTS AT RISK FOR LEFT VENTRICULAR DYSFUNCTION}

Several studies have tested the usefulness of BNP or NTproBNP in screening asymptomatic populations for heart failure. BNP and NT-proBNP are suboptimal for identifying asymptomatic cardiac dysfunction in the general population
[97-100]. In a population with low prevalence of heart failure, low levels of BNP or NT-proBNP may be able to rule out heart failure, but high values are not specific enough to rule in heart failure [97]. Although not useful for screening the general population, BNP and NT-proBNP tests may be beneficial for screening at risk populations for significant cardiac impairment for heart failure [101-103].

In patients at high risk for heart failure, BNP testing was able to identify patients with underlying cardiac dysfunction [101]. Heidenreich et al. showed that it is economically feasible to use a BNP cutoff value of $24 \mathrm{pg} / \mathrm{mL}$ to determine which patients to screen further using other, more expensive methods such as echocardiography [104]. Using this cutoff significantly decreased the costs of diagnosing patients with suspected cardiac dysfunction. In another study, BNP was used to test patients over the age of 65 and a group with a high number of cardiac risk factors [100]. The authors found that BNP was effective at screening for HF patients with area under the ROC curve of $0.83-0.88$ for the 65 years of older group and $0.83-0.85$ in the cohort with a high number of risk factors.

NT-proBNP is also useful in ruling out HF in primary care patients with suspected HF [105]. Omland et al. showed that elevated BNP levels were associated with increased risk of HF in patients with stable coronary artery disease, while NT-proBNP was associated with increased risk of heart failure as well as cardiovascular death and stroke [76]. More comparison studies with current automated BNP and NTproBNP assays are needed to determine their relative usefulness in this context.

\section{MONITORING AND GUIDING HEART FAILURE MANAGEMENT}

BNP and NT-proBNP may also be valuable in guiding therapeutic treatment for $\operatorname{HF}[9,34,106]$. As discussed, BNP may be more sensitive to hemodynamic changes in vivo [19, 56]. More research needs to be done to understand whether this impacts the relative effectiveness of BNP to monitor changes in patient prognosis following therapeutic intervention. For example, measurement of BNP may more accurately reflect recent changes in the production of BNP. Alternatively it could be overly sensitive in patients with wide swings in filling pressures. It has been shown that the disease modifying therapies in heart failure that reduce hospitalization and mortality also reduce natriuretic peptide levels chronically over time; these include: angiotensin converting enzyme inhibitors, angiotensin receptor blockers, betablockers, aldosterone-receptor antagonists, and biventricular pacing [107-110]. Thus, the concept that natriuretic peptide levels, analogous to glycohemoglobin in diabetes management, could be a treatment target for office physicians is worthy of randomized trials.

Data from the Strategies for Tailoring Advanced HF Regimens (STARS-BNP) clinical trial showed that monitoring patient BNP levels can augment proper titration of certain drug therapies to improve patient outcomes [111]. This study included 220 patients in the NYHA function class IIIII. Only 24\% patients who received BNP guided therapy died or were readmitted to the hospital during a 15-month period compared to $52 \%$ of patients that underwent unguided therapy. In the same study, it was found that event-free sur- 
vival was $84.3 \%$ in the BNP-guided group vs. $73.3 \%$ in the unguided group. In addition, $\mathrm{HF}$ related hospitalization dropped from $44 \%$ to $20 \%$ as a result of BNP-guided therapeutic modifications.

In a single-center trial of 73 patients with HF and ejection fraction $<40 \%$, Inomata et al. randomized patients to a BNP-guided strategy to a target BNP $<200 \mathrm{pg} / \mathrm{mL}$ versus usual care. The combined endpoint death or hospitalization occurred in $22 \%$ vs. $55 \%, \mathrm{p}=0.037$ over 25 months [112]. The Strategies for Tailoring Advance Heart Failure Regimens in the outpatient setting: BNP vs the clinical congestion score (STARBRITE) clinical trial pilot study assessed 130 patients with more advanced HF (NYHA class III-IV) [113]. In contrast to the STARS study, the pilot study found no significant change in the endpoint of readmission or death between patients that received BNP guided or unguided therapy. Thus, further research is needed to understand whether BNP guided therapy is advisable in patients with more progressive disease.

A randomized trial by Troughton et al. evaluated the role of NT-proBNP in guiding outpatient therapeutic intervention in class 2-4 $\mathrm{HF}$ patients with an ejection fraction $<40 \%$ [106]. The percent of patients that experienced a cardiovascular event within 6 months was $27 \%$ in the NT-proBNP guided group vs. $53 \%$ in the cohort that lacked NT-proBNP monitoring. Thus, NT-proBNP guided therapy also positively impacts patient outcome. Several large clinical trials, the BATTLESCARRED study, the PROTECT study and the TIME-CHF study are being undertaken to understand how NT-proBNP guided therapy impacts mortality and hospital admission rates in HF patients [114-116]. Head-to-head comparisons of current BNP and NT-proBNP for guiding patient therapy would be highly useful in the future.

\section{USEFULNESS OF CURRENT BNP AND NT-PROBNP ASSAYS IN PATIENTS RECEIVING NESIRITIDE THERAPY}

Recombinant BNP itself (nesiritide or Natricor) is used therapeutically in $\mathrm{HF}$ patient to ameliorate acute symptoms such as dyspnea and reduced cardiac output [117,118]. Treatment with these recombinant forms of BNP results in an inhibition of the renin-angiotensin system and aldosterone release, which promotes diuretic and vasodilatory effects. Endogenous BNP and NT-proBNP levels have been successfully measured in patients following treatment with nesiritide (recombinant hBNP) [119]. It has been shown that NTproBNP does not respond dynamically over the course of a nesiritide infusion, probably because of its longer half-life [119]. Nesiritide has an extremely short half-life of $18 \mathrm{~min}-$ utes [118]. Thus, although it has been argued that NTproBNP may be advantageous because nesiritide may obscure BNP levels, it is unlikely due to the half-life of the treatment. Measurement of BNP levels as soon as 2 hours after treatment should largely measure endogenously produced BNP; however, this needs to be tested. This represents an area where further study is needed to understand the relative usefulness of these assays in this cohort of HF patients.

\section{BNP AND NT-PROBNP ASSAYS IN ACUTE CORO- NARY SYNDROMES}

Measurement of circulating natriuretic peptides, BNP and NT-proBNP has found a secure place in the diagnosis, prog- nosis, and management of patients with heart failure. The natriuretic peptides have also been evaluated in the setting of acute coronary syndromes (ACS), primarily on the initial or baseline blood sample and have been found to be prognostic for in-hospital and short-term (6 month, 1 year) outcomes. The most recent ACC/AHA guidelines for the management of non-ST segment elevation ACS cite the use of natriuretic peptide management as a Class IIb indication: "Measurement of B-type natriuretic peptide (BNP) or NT-pro-BNP may be considered to supplement assessment of global risk in patients with suspected ACS. (Level of Evidence: B)" [129].

In the setting of stable angina, Omland et al. [130] showed that in patients with angiographically documented stable coronary artery disease, plasma BNP level was independently related to long-term survival. In their study, BNP level $>87 \mathrm{pg} / \mathrm{ml}$ (> 80th percentile) was associated with a survival rate of a little bit lower that $80 \%$ at 8 years compare to $90 \%$ at 8 years for patients with BNP $<87 \mathrm{pg} / \mathrm{ml}$. Richards et al. in a review [131], compared BNP and NT-proBNP in stable ischemic heart disease and concluded that, in this population, both natriuretic peptides correlated closely $(r=0.9, p<0.001)$, were powerful indicators of left ventricular function and independent predictors of clinical outcomes. Both peptides were similarly and independently influenced by gender, age, renal function and had the same performance in detecting left ventricular dysfunction.

In unstable angina and non-ST-segment elevation myocardial infarction, BNP and NT-proBNP levels have been shown to have similar prognostic value. Cameron et al. compared both peptides in emergency department in patients presenting with suspected ACS [132]. Despite the level of NT-proBNP being quantitatively higher than BNP, they were closely correlated $(r=0.89, p<0.0001)$ across subgroups of patients with coronary artery disease, hypertension, hypercholesterolemia, diabetes, all of which can influence vascular function and potentially left ventricular wall tension. The higher level of NT-pro BNP (median of $185 \mathrm{ng} / \mathrm{ml}$ compared to $15 \mathrm{ng} / \mathrm{ml}$ for BNP) might be explained by its prolonged half-life and greater reliance on glomerular filtration function for elimination.

De Lemos et al. studied the value of BNP in patients with unstable angina and non-ST-segment elevation myocardial infarction and showed that a single measurement of BNP obtained within 40 hours of the onset of ischemic symptoms can be used for risk stratification in ACS. In the same study, it was shown that BNP can be elevated, even in the absence of myocardial infarction [133]. Patient's exceeding the threshold of $80 \mathrm{pg} / \mathrm{ml}$, approximating the level of neurohormonal activation in heart failure $(100 \mathrm{pg} / \mathrm{ml})$, had an increased risk of 10 -month mortality $(\mathrm{OR}=5.8)$ compared to patients with BNP $<80 \mathrm{pg} / \mathrm{ml}$ [133]. Other authors found the same threshold as useful to identify patients at risk for heart failure and death at 6 months after ACS [134].

BNP itself also adds incremental prognostic information to other biomarkers including troponin I and CRP in patients with non-ST-segment elevation myocardial infarction. Sabatine in a review showed that patients with one, two or three elevated biomarkers had respectively $2.1,3.1$ and 3.7 fold increases in the risk of death, myocardial infarction, and congestive heart failure at 6 months [135]. 
NT-proBNP has also been assessed in non-ST-segment elevation myocardial infarction and unstable angina and has been found to improve early risk stratification. NT -pro BNP can be elevated in patients with normal troponin considered at low risk, allowing discrimination of patients at higher risk in this population. The NT-proBNP level range obtained on admission associated with risk of death in ACS is between 400 and $1000 \mathrm{pg} / \mathrm{ml}$ [136-139]. Weber et al. showed that a level $>474 \mathrm{pg} / \mathrm{ml}$ on admission adds incremental prognostic value in patients admitted for ACS without an elevation in troponin [136].

In ST-segment elevation myocardial infarction, Mega et al. demonstrated that a BNP level of more than $80 \mathrm{pg} / \mathrm{ml}$ at initial presentation identified patients at higher risk of death (seven fold higher) [139]. In the same study, increased concentration of BNP at initial presentation of patients with STsegment elevation myocardial infarction was associated with impaired reperfusion and fibrinolysis [140]. In ST-segment elevation myocardial infarction patients, BNP level has been associated with underlying severity of coronary artery disease and degree of ischemic myocardium. Palazzuoli et al. studied 88 patients with non-ST-segment elevation myocardial infarction and preserved ejection fraction, and found that BNP levels were significantly higher in patients with threevessel disease compared to patients with two or one vessel disease. Patients with left anterior descending artery stenosis had a higher BNP levels compared to patients with stenoses in other vessels [140]. This concept of the association between BNP and ischemia related increased in wall tension is supported by studies showing that there is an increase in BNP level after exercise thallium stress testing with significant ischemia and after transient ischemia induced by PCI [141].

The prognostic significance of large increase in BNP level has not been thoughroughly studied in the literature. In most of the studies, the cut point of BNP level associated with worse prognosis is $80 \mathrm{ng} / \mathrm{ml}$.

In a retrospective study done on 91 patients admitted with ST-segment elevation myocardial infarction, with BNP levels obtained within 24 hours of the patients admission, markedly elevated BNP levels (median, 25th percentile and 75th percentile of the BNP value were 366, 142 and 1011 $\mathrm{pg} / \mathrm{ml}$, respectively) predicted LAD and multivessel disease, reduced ejection fraction, diastolic dysfunction, and hemodynamic compromise including cardiogenic shock and the need for intra-aortic balloon counterpulsation early during hospitalization. In the same study, despite prompt angiography and primary PCI, substantial elevations of BNP was a prognostic marker of in-hospital mortality due to cardiovascular causes after ST-segment elevation myocardial infarction. These data suggest that, BNP level might predict not only the infarct size but also may portend cardiogenic shock in patients with ST-segment elevation myocardial infarction. [142].

Overall, BNP and NT-proBNP have a comparable prognostic value in stable angina, unstable angina, non-STsegment elevation myocardial infarction and ST-segment elevation myocardial infarction. The threshold value of BNP is lower than NT-proBNP most likely secondary to the size of the molecule, half-life and mode of elimination, which is different. Early neurohormonal activation in myocardial ischemia secondary to wall tension, or temporary or permanent left ventricular dysfunction secondary to ischemia, might explain why both peptides are elevated in ACS. Whether measurements one or both peptides on admission in patients with ACS, including patients considered otherwise at low risk without elevations of troponin, to assist in management decisions remains to be determined.

\section{CONCLUSIONS}

Testing for BNP or NT-proBNP has a significant impact on patient care and outcome in high-risk groups and in patients with suspected HF. The development of assays on automated instruments to test for these markers is a valuable tool for physicians and it is estimated that $70 \%$ of hospitals now have the capability to test for these markers [9]. Accurate diagnosis of $\mathrm{HF}$ and/or the ability to rule out suspected HF requires the use of BNP/NT-proBNP markers and clinical expertise, which together have been shown to greatly improve the accuracy of diagnosis in suspected HF patients. Prompt and appropriate use of therapeutic interventions can have a positive impact on patient quality of life and accurate markers of HF such as BNP and NT-proBNP are valuable for diagnosis and monitoring of HF patients in the ED and in high-risk populations.

In general, both markers are sensitive and specific markers of HF, which provide valuable prognostic information, improve patient care, and may be used to screen high-risk populations. BNP assays have the advantage of utilizing a single cutoff value for any age group. Thus, simpler, teachable algorithms are possible with BNP and not NT-proBNP. NT-proBNP levels are more significantly affected in elderly patients or in those with renal dysfunction, and thus, have lesser utility. In addition, a recent meta-analysis suggests that even with modified cutoff values BNP may be a superior diagnostic tool in elderly patients (44). In addition, although both markers have been shown to improve patient outcomes when used to guide admission decisions and/or therapy, head-to-head comparisons should be done to directly compare the usefulness of these assays in the longitudinal management of heart failure.

Measurement of natriuretic peptides in the setting of ACS identifies patients at high risk for short-term outcomes in including the development of HF, rehospitalization, and death. This application is germane to patients with unstable angina, non-ST-segment elevation myocardial infarction, and ST-segment elevation myocardial infarction. The elevation of BNP and NT-proBNP appears to reflect the area of ischemic myocardium at risk, severity of coronary disease, and impending LV dysfunction.

It should be noted that levels of both peptides are found to be lower in normals and in those with HF among the obese. This may be related to enhanced clearance of the peptides. Malavazos and colleagues have described a relationship between epicardial fat and increased levels of NTproBNP that suggest either myocardial triglyceride content or the paracrine effect of adipokines may be related to increased wall tension, left ventricular hypertrophy, and production of natriuretic peptides [143]. Clearly more research is needed in this area.

Finally, the use of natriuretic peptides can be seen as a major advance in the diagnosis, prognosis, screening, and 
management of CVD. Future studies that use these markers in treatment pathways to improve outcomes are anticipated.

\section{ACKNOWLEDGEMENTS}

We wish to acknowledge Amy Mckee and Fred W. Peyerl from Boston Strategic Partners for technical assistance in the literature search process and development of evidence tables.

\section{FUNDING}

Funding for technical assistance was provided to Boston Strategic Partners by Abbott Diagnostics, Inc., Chicago, IL. No funding was provided to authors.

\section{REFERENCES}

[1] Jondeau G. The difficulty in diagnosing heart failure in the elderly. Presse Med 2004; 33: 1083-5.

[2] Fonseca C. Diagnosis of heart failure in primary care. Heart Fail Rev 2006; 11: 95-107.

[3] Ahmed A. Clinical manifestations, diagnostic assessment, and etiology of heart failure in older adults. Clin Geriatr Med 2007; 23: 11-30.

[4] Remes J, Miettinen H, Reunanen A, Pyorala K. Validity of clinical diagnosis of heart failure in primary health care. Eur Heart J 1991; 12: 315-21.

[5] Wheeldon NM, MacDonald TM, Flucker CJ, McKendrick AD, McDevitt DG, Struthers AD. Echocardiography in chronic heart failure in the community. Q J Med 1993; 86: 17-23.

[6] Breidthardt T, Laule K, Strohmeyer AH, et al. Medical and economic long-term effects of B-type natriuretic peptide testing in patients with acute dyspnea. Clin Chem 2007; 53: 1415-22.

[7] Richards AM, Doughty R, Nicholls MG, et al. Neurohumoral prediction of benefit from carvedilol in ischemic left ventricular dysfunction. Australia-New Zealand Heart Failure Group. Circulation 1999; 99: 786-92.

[8] Richards AM, Doughty R, Nicholls MG, et al. Plasma N-terminal pro-brain natriuretic peptide and adrenomedullin: prognostic utility and prediction of benefit from carvedilol in chronic ischemic left ventricular dysfunction. Australia-New Zealand Heart Failure Group. J Am Coll Cardiol 2001; 37: 1781-7.

[9] Silver MA, Maisel A, Yancy CW, et al. BNP Consensus Panel 2004: A clinical approach for the diagnostic, prognostic, screening, treatment monitoring, and therapeutic roles of natriuretic peptides in cardiovascular diseases. Congest Heart Fail 2004; 10: 1-30.

[10] Mueller C, Breidthardt T, Laule-Kilian K, Christ M, Perruchoud AP. The integration of BNP and NT-proBNP into clinical medicine. Swiss Med Wkly 2007; 137: 4-12.

[11] Felker GM, Petersen JW, Mark DB. Natriuretic peptides in the diagnosis and management of heart failure. Can Med Assoc J 2006; 175: 611-7.

[12] Davis M, Espiner E, Richards G, et al. Plasma brain natriuretic peptide in assessment of acute dyspnoea. Lancet 1994; 343: 440-4.

[13] Mukoyama M, Nakao, K, Hosoda, K. Brain natriuretic peptide as a novel cardiac hormone in humans. Evidence for an exquisite dual natriuretic peptide system. J Clin Invest 1991; 87: 1402-12.

[14] Yoshimura M, Yasue H, Okumura K. Different secretion patterns of atrial natriuretic peptide in patients with congestive heart failure. Circulation 1993; 87: 464-9.

[15] Doust JA, Glasziou PP, Pietrzak E. A systematic review of the diagnostic accuracy of natriuretic peptides for heart failure. Arch Intern Med 2004; 164: 1978-84

[16] Tsutamoto T, Wada A, Maeda K, et al. Attenuation of compensation of endogenous cardiac natriuretic peptide system in chronic heart failure: prognostic role of plasma brain natriuretic peptide concentration in patients with chronic symptomatic left ventricular dysfunction. Circulation 1997; 96: 509-16.

[17] Omland T, Aakvaag A, Bonarjee VV, et al. Plasma brain natriuretic peptide as an indicator of left ventricular systolic function and long-term survival after acute myocardial infarction. Comparison with plasma atrial natriuretic peptide and $\mathrm{N}$-terminal proatrial natriuretic peptide. Circulation 1996; 93: 1963-9.
[18] Mair J, Hammerer-Lercher A, Puschendorf B. The impact of cardiac natriuretic peptide determination on the diagnosis and management of heart failure. Clin Chem Lab Med 2001; 39: 571-87.

[19] Kazanegra R, Cheng V, Garcia A, et al. A rapid test for B-type natriuretic peptide correlates with falling wedge pressures in patients treated for decompensated heart failure: a pilot study. J Card Fail 2001; 7: 21-29.

[20] de Lemos JA, Morrow DA, Bentley JH, et al. The prognostic value of B-type natriuretic peptide in patients with acute coronary syndromes. N Engl J Med 2001; 345: 1014-21.

[21] James SK, Lindahl B, Siegbahn A, et al. N-terminal pro-brain natriuretic peptide and other risk markers for the separate prediction of mortality and subsequent myocardial infarction in patients with unstable coronary artery disease: a Global Utilization of Strategies To Open occluded arteries (GUSTO)-IV substudy. Circulation 2003; 108: 275-81

[22] Liang F, O'Rear J, Schellenberger U, et al. Evidence for functional heterogeneity of circulating B-type natriuretic peptide. J Am Coll Cardiol 2007; 49: 1071-8

[23] Hawkridge AM, Heublein DM, Bergen HR, 3rd, Cataliotti A, Burnett JC Jr, Muddiman DC. Quantitative mass spectral evidence for the absence of circulating brain natriuretic peptide (BNP-32) in severe human heart failure. Proc Natl Acad Sci USA 2005; 102: $17442-7$

[24] Lam CS, Burnett JC Jr, Costello-Boerrigter L, Rodeheffer RJ, Redfield MM. Alternate circulating pro-B-type natriuretic peptide and B-type natriuretic peptide forms in the general population. $\mathrm{J}$ Am Coll Cardiol 2007; 49: 1193-202.

[25] Goetze JP, Jensen G, Moller S, Bendtsen F, Rehfeld JF, Henriksen JH. BNP and N-terminal proBNP are both extracted in the normal kidney. Eur J Clin Invest 2006; 36: 8-15.

[26] Schou M, Dalsgaard MK, Clemmesen O, et al. Kidneys extract BNP and NT-proBNP in healthy young men. J Appl Physiol 2005; 99: $1676-80$.

[27] Pankow K, Wang Y, Gembardt F, et al. Successive action of meprin A and neprilysin catabolizes B-type natriuretic peptide. Circ Res 2007; 101: 875-82.

[28] McCullough PA, Duc P, Omland T, et al. B-type natriuretic peptide and renal function in the diagnosis of heart failure: an analysis from the Breathing Not Properly Multinational Study. Am J Kidney Dis 2003; 41: 571-9.

[29] Wang CS, FitzGerald JM, Schulzer M. Does this dyspneic patient in the emergency department have congestive heart failure? JAMA 2005; 294: 1944-56.

[30] Nieminen MS, Bohm M, Cosie MR, et al. Executive summary of the guidelines on the diagnosis and treatment of acute heart failure. The Task Force on Acute Heart Failure of the European Society of Cardiology. Eur Heart J 2005; 26: 284-16.

[31] Swedberg K, Cleland J, Dargie H, et al. Guidelines for the diagnosis and treatment of chronic heart failure: executive summary (update 2005). Eur Heart J 2005; 26: 1115-40.

[32] Hunt SA. ACC/AHA 2005 guideline update for the diagnosis and management of chronic heart failure in the adult: a report of the American College of Cardiology/American Heart Association Task Force on Practice Guidelines (Writing Committee to Update the 2001 Guidelines for the Evaluation and Management of Heart Failure). J Am Coll Cardiol 2005; 46: e1-82.

[33] Tang WH, Francis GS, Morrow DA, et al. National Academy of Clinical Biochemistry Laboratory Medicine Practice Guidelines: clinical utilization of cardiac biomarker testing in heart failure. Clin Biochem 2008; 41: 210-221.

[34] Bettencourt P, Ferreira S, Azevedo A, Ferreira A. Preliminary data on the potential usefulness of B-type natriuretic peptide levels in predicting outcome after hospital discharge in patients with heart failure. Am J Med 2002; 113: 215-9.

[35] Dao Q, Krishnaswamy P, Kazanegra R, et al. Utility of B-type natriuretic peptide in the diagnosis of congestive heart failure in an urgent-care setting. J Am Coll Cardiol 2001; 37: 379-85.

[36] Maisel AS, Krishnaswamy P, Nowak RM, et al. Rapid measurement of B-type natriuretic peptide in the emergency diagnosis of heart failure. N Engl J Med 2002; 347: 161-7.

[37] Villacorta H, Duarte A, Duarte NM, et al. The role of B-type natriuretic peptide in the diagnosis of congestive heart failure in patients presenting to an emergency department with dyspnea. Arq Bras Cardiol 2002; 79: 564-8. 
[38] Ray P, Arthaud M, Lefort Y, Birolleau S, Beigelman C, Riou B. EPIDASA Study Group: Usefulness of B-type natriuretic peptide in elderly patients with acute dyspnea. Intensive Care Med 2004; 30: 2230-6.

[39] Zaninotto M, Mion M, Altinier S, et al. NT-proBNP in the differential diagnosis of acute dyspnea in the emergency department. Clin Biochem 2005; 38: 1041-4.

[40] Bayes-Genis A, Santalo-Bel M, Zapico-Munez E, et al. N-terminal probrain natriuretic peptide (NT-proBNP) in the emergency diagnosis and in-hospital monitoring of patients with dyspnoea and ventricular dysfunction. Eur J Heart Fail 2004; 6: 301-8.

[41] Mc Donagh TA, Holmer S, Raymond I, Luchner A, Hildebrant P, Dargie HJ. NT-proBNP and the diagnosis of heart failure: a pooled analysis of three European epidemiological studies. Eur J Heart Fail 2004; 6: 269-73.

[42] McCullough PA, Nowak RM, McCord J, et al. B-type natriuretic peptide and clinical judgment in emergency diagnosis of heart failure: analysis from Breathing Not Properly (BNP) Multinational Study. Circulation 2002; 106: 416-22.

[43] Januzzi JL Jr, Camargo CA, Anwaruddin S, et al. The N-terminal Pro-BNP investigation of dyspnea in the emergency department (PRIDE) study. Am J Cardiol 2005; 95: 948-54.

[44] Baggish AL, Siebert U, Lainchbury JG, et al. A validated clinical and biochemical score for the diagnosis of acute heart failure: the ProBNP Investigation of Dyspnea in the Emergency Department (PRIDE) Acute Heart Failure Score. Am Heart J 2006; 151: 48-54.

[45] Zaphiriou A, Robb S, Murray-Thomas T, et al. The diagnostic accuracy of plasma BNP and NTproBNP in patients referred from primary care with suspected heart failure: results of the UK natriuretic peptide study. Eur J Heart Fail 2005; 7: 537-41.

[46] Nielsen LS, Svanegaard J, Klitgaard NA, Egeblad H. N-terminal pro-brain natriuertic peptide for discriminating between cardiac and non-cardiac dyspnoea. Eur J Heart Fail 2004; 6: 63-70.

[47] Jose JV, Gupta SN, Selvakumar D. Utility of N-terminal pro-brain natriuretic peptide for the diagnosis of heart failure. Indian Heart $\mathbf{J}$ 2003; 55: 35-9.

[48] Mueller C, Laule-Kilian K, Schindler C, et al. Cost-effectiveness of B-type natriuretic peptide testing in patients with acute dyspnea. Arch Intern Med 2006; 166: 1081-7.

[49] Moe GW, Howlett JH, Januzzi JL, Zowall MA. N-Terminal Pro-BType natriuertic peptide testing improves the managements of patients with suspected acute heart failure. Circulation 2007; 115: 3103-3110.

[50] Clerico A, Fontanna M, Zyw L, Passino C, Emdin M. Comparison of the Diagnostic Accuracy of Brain Natriuretic Peptide (BNP) and the N-terminal part of the propeptide of BNP immunoassays in chronic and acute heart failure: a systematic review. Clin Chem 2007; 53: 813-22.

[51] Mueller C. Comparison of the diagnostic accuracy of BNP and NTproBNP in acute and chronic heart failure. Clin Chem 2007; 53: 1719-20.

[52] Clerico A, Fontana M, Zyw L, Passino C, Emdin M. Response to Letter to the Editor. Clin Chem 2007; 53: 1721-2.

[53] Davenport C, Cheng EY, Kwok YT, et al. Assessing the diagnostic test accuracy of natriuretic peptides and ECG in the diagnosis of left ventricular systolic dysfunction: a systematic review and metaanalysis. Br J Gen Pract 2006; 56: 48-56.

[54] Ewald B, Ewald D, Thakkinstian A, Attia J. Meta-analysis of B type natriuretic peptide and $\mathrm{N}$-terminal pro $\mathrm{B}$ natriuretic peptide in the diagnosis of clinical heart failure and population screening for left vetricular systolic dysfunction. Intern Med J 2008; 38: 101-13.

[55] Worster A, Balion CM, Hill SA, et al. Diagnostic accuracy of BNP and NT-proBNP in patients presenting to acute care settings with dyspnea: A systematic review. Clin Biochem 2008; 41: 250-9.

[56] Mair J, Falkensammer G, Poelzl G, Hammerer-Lercher A, Griesmacher A, Pachinger O. B-type natriuretic peptide (BNP) is more sensitive to rapid hemodynamic changes in acute heart failure than N-terminal proBNP. Clin Chim Acta 2007; 379: 163-6.

[57] Rich MW, Beckham V, Wittenberg C, Leven CL, Freedland KE, Carney RM. A multidisciplinary intervention to prevent the readmission of elderly patients with congestive heart failure. $\mathrm{N}$ Engl $\mathrm{J}$ Med 1995; 333: 1190-5.

[58] McAlister FA, Lawson FM, Teo KK, Armstrong PW. A systematic review of randomized trials of disease management programs in heart failure. Am J Med 2001; 110: 378-84.
[59] Fox KF, Cowie MR, Wood DA, et al. Coronary artery disease as the cause of incident heart failure in the population. Eur Heart $\mathrm{J}$ 2001; 22: 228-36.

[60] Cleland JG, Swedberg K, Follath F, et al. The EuroHeart Failure survey programme-- a survey on the quality of care among patients with heart failure in Europe. Part 1: patient characteristics and diagnosis. Eur Heart J 2003; 24: 442-63.

[61] Logeart D, Thabut G, Jourdain P, et al. Predischarge B-type natriuretic peptide assay for identifying patients at high risk of readmission after decompensated heart failure. J Am Coll Cardiol 2004; 43: 635-41.

[62] Harrison A, Morrison LK, Krishnaswamy P, et al. B-type natriuretic peptide predicts future cardiac events in patients presenting to the emergency department with dyspnea. Ann Emerg Med 2002; 39: 131-8.

[63] Aspromonte N, Feola M, Milli M, et al. Prognostic role of B-type natriuretic peptide in patients with diabetes and acute decompensated heart failure. Diabet Med 2007; 24: 124-30.

[64] Valle R, Prevaldi C, D'Eri A, et al. B-type natriuretic peptide predicts post-discharge prognosis in elderly patients admitted due to cardiogenic pulmonary edema. Am J Geriatr Cardiol 2006; 15: 202-7.

[65] Christ M, Laule-Kilian K, Hochholzer W, et al. Gender-specific risk stratification with B-type natriuretic peptide levels in patients with acute dyspnea: insights from the B-type natriuretic peptide for acute shortness of breathe evaluation study. J Am Coll Cardiol 2006; 48: 1808-12.

[66] Bettencourt P, Azevedo A, Pimenta J, Frioes F, Ferreira S, Ferreira A. N-terminal-pro-brain natriuretic peptide predicts outcome after hospital discharge in heart failure patients. Circulation 2004; 110: 2168-74.

[67] Kubler P, Petruk-Kowalczyk J, Majda J, Reczuch K, Banasiak W, Ponikowski P. Persistent high NTpro-BNP concentration as a negative prognostic factor in patients with decompensated heart failure. Kardiol Pol 2006; 64: 250-6; discussion 257-8.

[68] Bibbins-Domingo K, Gupta R, Na B, Wu AH, Schiller NB, Whooley MA. N-terminal fragment of the prohormone brain-type natriuretic peptide (NT-proBNP), cardiovascular events, and mortality in patients with stable coronary heart disease. JAMA 2007; 297: 212-4.

[69] Pereira-Barretto AC, de Oliveira MT Jr, Strunz CC, Del Carlo CH, Scipioni AR, Ramires JA. Serum NT-proBNP levels are a prognostic predictor in patients with advanced heart failure. Arq Bras Cardiol 2006; 87: 174-7.

[70] Bayes-Genis A, Lopez L, Zapico E, et al. NT-ProBNP reduction percentage during admission for acutely decompensated heart failure predicts long-term cardiovascular mortality. J Card Fail 2005; 11: S3-8

[71] Januzzi JL, Sakhuja R, O'donoghue M, et al. Utility of aminoterminal pro-brain natriuretic peptide testing for prediction of 1year mortality in patients with dyspnea treated in the emergency department. Arch Intern Med 2006; 166: 315-20.

[72] Shou M, Gustafsson F, Corell P, Kistorp CN, Kjaer A, Hildebrandt $\mathrm{PR}$. The relationship between N-terminal pro-brain natriuretic peptide and risk for hospitalization and mortality is curvilinear in patients with chronic heart failure. Am Heart J 2007; 154: 123-9.

[73] O'Donoghue M, Kenney P, Oestreicher E, et al. Usefulness of aminoterminal pro-brain natriuretic peptide testing for the diagnostic and prognostic evaluation of dyspneic patients with diabetes mellitus seen in the Emergency Department (from the PRIDE Study). Am J Cardiol 2007; 100: 1336-40.

[74] Masson S, Latini R, Anand IS, et al. Direct comparison of B-type natriuretic peptide (BNP) and amino-terminal proBNP in a large population of patients with chronic and symptomatic heart failure: the Valsartan Heart Failure (Val-HeFT) data. Clin Chem 2006; 52: 1528-38.

[75] Waldo SW, Beede J, Isakson S, et al. Pro-B-type natriuretic peptide levels in acute decompensated heart failure. J Am Coll Cardiol 2008; 51: 1874-82

[76] Omland T, Sabatine MS, Jablonski KA, et al. Prognostic value of B-Type natriuretic peptides in patients with stable coronary artery disease: the PEACE Trial. J Am Coll Cardiol 2007; 50: 205-14.

[77] McKie PM, Rodeheffer RJ, Cataliotti A, et al. Amino-terminal proB-type natriuretic peptide and B-type natriuretic peptide: biomarkers for mortality in a large community-based cohort free of heart failure. Hypertension 2006; 47: 874-80. 
[78] Maisel AS, Clopton P, Krishnaswamy P, et al. Impact of age, race, and sex on the ability of B-type natriuretic peptide to aid in the emergency diagnosis of heart failure: results from the Breathing Not Properly (BNP) multinational study. Am Heart J 2004; 147: 1078-84.

[79] Redfield MM, Rodeheffer RJ, Jacobsen SJ, et al. Plasma brain natriuretic peptide concentration: impact of age and gender. J Am Coll Cardiol 2002; 40: 976-82.

[80] Krauser DG, Chen AA, Tung R, Anwaruddin S, Baggish AL, Januzzi JL Jr. Neither race nor gender influences the usefulness of amino-terminal pro-brain natriuretic peptide testing in dyspneic subjects: a ProBNP Investigation of Dyspnea in the Emergency Department (PRIDE) substudy. J Card Fail 2006; 12: 452-7.

[81] McCullough PA, Hollander JE, Nowak RM, et al. Uncovering heart failure in patients with a history of pulmonary disease: rationale for the early use of B-type natriuretic peptide in the emergency department. Acad Emerg Med 2003; 10: 198-204.

[82] Morrison LK, Harrison A, Krishnaswamy P, Kazanegra R, Clopton $\mathrm{P}$, Maisel A. Utility of a rapid B-natriuretic peptide assay in differentiating congestive heart failure from lung disease in patients presenting with dyspnea. J Am Coll Cardiol 2002; 39: 202-9.

[83] Tung RH, Camarogo CA Jr, Krauser D, et al. Amino-terminal probrain natriuretic peptide for the diagnosis of actue heart failure in patients with previous obstructive airway disease. Ann Emerg Med 2006; 48: 66-74

[84] Taylor JA, Christenson RH, Rao K, Jorge M, Gottlieb SS. B-type natriuretic peptide and $\mathrm{N}$-terminal pro B-type natriuretic peptide are depressed in obesity despite higher left ventricular end diastolic pressures. Am Heart J 2006; 152: 1071-6.

[85] Iwanaga Y, Kihara Y, Niizuma S, et al. BNP in overweight and obese patients with heart failure: an analysis based on the BNP-LV diastolic wall stress relationship. J Card Fail 2007; 13: 663-7.

[86] Kalsch H, Neumann T, Erbel R. Less increase of BNP and NTproBNP levels in obese patient with decompensated heart failure Interpretation of natriuretic peptides in obesity. Int J Cardiol 2009; 33(1): e22-4.

[87] Bayes-Genis A, DeFilippi C, Januzzi JL Jr. Understanding aminoterminal pro-B-type natriuretic peptide in obesity. Am J Cardiol 2008; 101: 89-94.

[88] van Kimmenade R, van Dielen F, Bakker J, et al. Is brain natriuretic peptide production decreased in obese subjects? J Am Coll Cardiol 2006; 47: 886-7.

[89] Krauser DG, Lloyd-Jones DM, Chae CU, et al. Effect of body mass index on natriuretic peptide levels in patients with acute congestive heart failure: a ProBNP Investigation of Dyspnea in the Emergency Department (PRIDE) substudy. Am Heart J 2005; 149: 744-50.

[90] Anwaruddin S, Lloyd-Jones DM, Baggish A, et al. Renal function, congestive heart failure, and amino-terminal pro-brain natriuretic peptide measurement: results from the ProBNP Investigation of Dyspnea in the Emergency Deparment (PRIDE) study. J Am Coll Cardiol 2006; 48: 1060-1.

[91] DeFrances CJ, Hall MJ. 2005 National hospital discharge survey. Adv Data 2007; (385): 1-19.

[92] Hillege HL, Girbes AR, de Kam PJ, et al. Renal function, neurohormonal activation, and survival in patients with chronic heart failure. Circulation 2000; 102: 203-10.

[93] Weinfeld MS, Chertow GM, Stevenson LW. Aggravated renal dysfunction during intensive therapy for advanced chronic heart failure. Am Heart J 1999; 138: 285-90.

[94] Anand IS, Chugh SS. Mechanisms and management of renal dysfunction in heart failure. Curr Opin Cardiol 1997; 12: 251-8.

[95] Austin WJ, Bhalla V, Hernandez-Arce I, et al. Correlation and prognostic utility of B-type natriuretic peptide and its aminoterminal fragment in patients with chronic kidney disease. Am J Clin Pathol 2006; 126: 506-12.

[96] Richards AM, Nicholls GM, Espiner EA, et al. Comparison of Btype natriuretic peptides for assessment of cardiac function and prognosis in stable ischemic heart disease. J Am Coll Cardiol 2006; 47: $52-60$

[97] Hill SA, Balion CM, Santaguida P, et al. Evidence for the use of Btype natriuretic peptides for screening asymptomatic populations and for diagnosis in primary care. Clin Biochem 2008; 41: 240-9.

[98] Redfield MM, Rodeheffer RJ, Jacobsen SJ, Mahoney DW, Bailey KR, Burnett JC Jr. Plasma brain natriuretic peptide to detect preclinical ventricular systolic or diastolic dysfunction: a communitybased study. Circulation 2004; 109: 3176-81.
[99] Vasan RS, Benjamin EJ, Larson MG, et al. Plasma natriuretic peptides for community screening for left ventricular hypertrophy and systolic dysfunction: the Framingham heart study. JAMA 2002; 288: 1252-9.

[100] Nakamura S, Tanaka F, Sato K, Segawa T, Nagano M. B-type natriuretic peptide testing for structural heart diesease screening: a general population-based study. J Card Fail 2006; 11: 705-12.

[101] Silver MA, Pisano C. High incidence of elevated B-type natriuretic peptide levels and risk factors for heart failure in an unselected atrisk population (stage A): implications for heart failure screening programs. Congest Heart Fail 2003; 9: 127-32.

[102] Cowie MR, Struthers AD, Wood DA, et al. Value of natriuretic peptides in assessment of patients with possible new heart failure in primary care. Lancet 1997; 350: 1349-53.

[103] Costello-Boerrigter LC, Boerrigter G, Redfield MM, Rodeheffer RJ, Urban LH, Mahoney DW. Amino-terminal pro-B-type natriuretic peptide and B-type natriuretic peptide in the general community: determinants and detection of left ventricular dysfunction. J Am Coll Cardiol 2006; 47(2): 345-53.

[104] Heidenreich PA, Gubens MA, Fonarow GC, Konstam MA, Stevenson LW, Shekelle PG. Cost-effectiveness of screening with B-type natriuretic peptide to identify patients with reduced left ventricular ejection fraction. J Am Coll Cardiol 2004; 43: 1019-26.

[105] Gustafsson F, Steensgaard-Hansen F, Badskjaer J, Poulsen AH, Corell P, Hildebrandt P. Diagnostic and prognostic performance of $\mathrm{N}$-terminal ProBNP in primary care patients with suspected heart failure. J Card Fail 2005; 11: S15-S20.

[106] Troughton RW, Frampton CM, Yandle TG, Espiner EA, Nicholls MG, Richards AM. Treatment of heart failure guided by plasma aminoterminal brain natriuretic peptide (N-BNP) concentrations. Lancet 2000; 355: 1126-30.

[107] Madrid HA, Diaz MM, Cervantes EC, et al. Usefulness of brain natriuretic peptide to evaluate patients with heart failure treated with cardiac resynchronization. Rev Esp Cardiol 2004; 57: 299305 .

[108] Fung JW, Yu CM, Yip G, et al. Effect of beta blockade (carvedilol or metoprolol) on activation of the renin-angiotensin-aldosterone system and natriuretic peptides in chronic heart failure. Am J Cardiol 2003; 92: 406-410.

[109] Rousseau MF, Gurne O, Duprez D, et al. Beneficial neurohormonal profile of spironolactone in severe congestive heart failure: results from the RALES neurohormonal substudy. J Am Coll Cardiol 2002; 40: 1596-601.

[110] Sheth T, Parker T, Block A, et al. Comparison of the effects of omapatrilat and lisinopril on circulating neurohormones and cytokines in patients with chronic heart failure. Am J Cardiol 2002; 90: 496-500.

[111] Jourdain P, Jondeau G, Funck F, et al. Plasma brain natriuretic peptide-guided therapy to improve outcome in heart failure: the STARS-BNP Multicenter Study. J Am Coll Cardiol 2007; 49: 1733-9.

[112] Inomata TNM, Takehana $\mathrm{H}$, Nakahata $\mathrm{J}$, et al. Brain natriuretic peptide-guided treatment reduces cardiovascular events of heart failure in outpatient management. Circulation 2003; 108(17): IV446, \#2053.

[113] Shah MR, Claise KA, Bowers MT, et al. Testing new targets of therapy in advanced heart failure: the design and rationale of the Strategies for Tailoring Advanced Heart Failure Regimens in the Outpatient Setting: BRain Natrluretic Peptide Versus the Clinical CongesTion ScorE (STARBRITE) trial. Am Heart J 2005; 150: 893-8.

[114] Clinicaltrials.gov: 2007

[115] Lainchbury JG, Troughton RW, Frampton CM, et al. NTproBNPguided drug treatment for chronic heart failure: design and methods in the "BATTLESCARRED" trial. Eur J Heart Fail 2006; 8: 532-8.

[116] Brunner-La Rocca HP, Buser PT, Schindler R, Bernheim A, Rickenbacher P, Pfisterer M. Management of elderly patients with congestive heart failure--design of the Trial of Intensified versus standard Medical therapy in Elderly patients with Congestive Heart Failure (TIME-CHF). Am Heart J 2006; 151: 949-55.

[117] Moe GW. B-type natriuretic peptide in heart failure. Curr Opin Cardiol 2006; 21: 208-14.

[118] Hobbs RE, Mills RM. Therapeutic potential of nesiritide (recombinant b-type natriuretic peptide) in the treatment of heart failure. Expert Opin Investig Drugs 1999; 8: 1063-72. 
[119] Fitzgerald RL, Cremo R, Gardetto N, et al. Effect of nesiritide in combination with standard therapy on serum concentrations of natriuretic peptides in patients admitted for decompensated congestive heart failure. Am Heart J 2005; 150: 471-7.

[120] Lainchbury JG, Campbell E, Frampton CM, Yandle TG, Nicholls MG, Richards AM. Brain natriuretic peptide and n-terminal brain natriuretic peptide in the diagnosis of heart failure in patients with acute shortness of breath. J Am Coll Cardiol 2003; 42: 728-5.

[121] Alibay Y, Beauchet A, El Mahmoud R, Schmitt C, Brun-Ney D, Benoit MO. Plasma N-terminal pro-brain natriuretic peptide and brain natriuretic peptide in assessment of acute dyspnea. Biomed Pharmacother 2005; 59: 20-4.

[122] Ray P, Arthaud M, Birolleau S, et al. Comparison of brain natriuretic peptide and probrain natriuretic peptide in the diagnosis of cardiogenic pulmonary edema in patients aged 65 and older. J Am Geriatr Soc 2005; 53: 643-8.

[123] Chenevier-Gobeaux C, Claessens YE, Voyer S, Desmoulins D, Ekindjian OG. Influence of renal function on N-terminal pro-brain natriuretic peptide (NT-proBNP) in patinets admitted for dyspnoea in the Emergency Department: comparison with brain natriuretic peptide (BNP). Clin Chim Acta 2005; 361: 167-75.

[124] Gegenhuber A, Struck J, Poelz W, et al. Midregional pro-A-type natriuretic peptide measurements for diagnosis of acute destabilized heart failure in short-of-breath patients: comparison with Btype natriuretic peptide (BNP) and amino-terminal proBNP. Clin Chem 2006; 52: 827-31.

[125] Sanz MP, Borque L, Rus A, Vicente B, Ramirez Y, Lasa L. Comparison of BNP and NT-proBNP assays in the approach to the emergency diagnosis of acute dyspnea. J Clin Lab Anal 2006; 20 : 227-32.

[126] Mueller T, Gegenhuber A, Poetz W, Haltmayer M. Biochemical diagnosis of impaired left ventricular ejection fraction: comparison of the diagnostic accuracy of brain natriuretic peptide (BNP) and amino terminal proBNP (NT-proBNP. Clin Chem Lab Med 2004; 42: 159-63.

[127] Bhalla V, Isakson S, Bhalla MA, Jin JP, Clopton P, Gardetto N. Diagnostic ability of B-type natriuretic peptide and impedance hypertensive patients. Am J Hypertens 2005; 18: 73S-81S.

[128] Zaphiriou A, Robb S, Murray-Thomas T, Mendez G, Fox K, McDonagh T. The diagnostic accuracy of plasma BNP and NTproBNP in patients referred from primary care with suspected heart failure: results of the UK natriuretic peptide study. Eur J Heart Fail 2005; 7: 537-41.

[129] Anderson JL, Adams CD, Antman EM, et al. American College of Cardiology; American Heart Association Task Force on Practice Guidelines (Writing Committee to Revise the 2002 Guidelines for the Management of Patients With Unstable Angina/Non-STElevation Myocardial Infarction); American College of Emergency Physicians; Society for Cardiovascular Angiography and Interventions; Society of Thoracic Surgeons; American Association of Cardiovascular and Pulmonary Rehabilitation; Society for Academic Emergency Medicine. ACC/AHA 2007 guidelines for the management of patients with unstable angina/non-ST-Elevation myocardial infarction: a report of the American College of Cardiology/American Heart Association Task Force on Practice Guidelines (Writing Committee to Revise the 2002 Guidelines for the Management of Patients With Unstable Angina/Non-ST-Elevation Myocardial Infarction) developed in collaboration with the Ameri- can College of Emergency Physicians, the Society for Cardiovascular Angiography and Interventions, and the Society of Thoracic Surgeons endorsed by the American Association of Cardiovascular and Pulmonary Rehabilitation and the Society for Academic Emergency Medicine. J Am Coll Cardiol. 2007; 50(7): e1-e157. No abstract available. Erratum in: J Am Coll Cardiol. 2008 Mar 4; 51(9): 974.]

[130] Tobjorn O, Mark R, Ragnhild W, Vik-Mo Harald. B-Type natriuretic peptide and long-term survival in patients with stable coronary artery disease. Am J Cardiol 2005; 95: 24-28.

[131] Richards M, Nicholls G, Espiner AE, et al. Comparison of B-Type natriuretic peptides for assessment of cardiac function and prognosis in stable ischemic heart disease. J Am Coll Cardiol 2006; 47 : 52-60.

[132] Cameron JS, Green BG, White CN, et al. Assessment of BNP and NT-proBNP in emergency departments patients presenting with suspected acute coronary syndromes. Clin Biochem 2006; 39: 11-8.

[133] De Lamos AJ, Morrow AD, Bentley HJ, et al. The prognosis value of B-Type natriuretic peptide in patients with acute coronary syndrome. N Engl J Med 2001; 345: 1014-21.

[134] Morrow AD, De Lamos AJ, Sabatine SM, et al. Evaluation of Btype natriuretic peptide for risk assessment in unstable angina/ non -ST-elevation myocardial infarction. J Am Coll Cardiol 2003; 41: 1264-72.

[135] Sabatine SM, Morrow AD, De lamos AJ, et al. Multimarker approach to risk stratification in non-ST elevation acute coronary syndromes: simultaneous assessment of troponin I, C-reactive protein, and B-type natriuretic peptide. Circulation 2002; 105: 1760-3.

[136] Weber M, Bazzino O, Estrada N, et al. N-Terminal B-type natriuretic peptide assessment provides incremental prognostic information in patients with acute coronary syndromes and normal troponin T values upon admission. J Am Coll Cardiol 2008; 51: 1188-95.

[137] Tomas J, Mats S, Per V, Bertil L. N-terminal pro Brain natriuretic peptide on admission for early risk stratification of patients with chest pain and no-ST-segment elevation. J Am Coll Cardiol 2002; 40: 437-45.

[138] Torjborn O, Anita P, Leong NG, et al. N-terminal pro-B-type natriuretic peptide and long term mortality in acute coronary syndrome. Circulation 2002; 106; 2913-8.

[139] Heeschen C, Hamm WC, Mitrovic V, et al. N-terminal pro-B-type natriuretic peptide levels for dynamic risk stratification of patients with acute coronary syndrome. Circulation 2004; 110; 3206-12.

[140] Mega LJ, Morrow AD, Lemos AJ, et al. B-type natriuretic peptide at presentation and prognosis in patients with ST-segment elevation myocardial infarction. J Am Coll Cardiol 2004; 44: 335-9.

[141] Palazzuoli A, Gennari L, Calabria P, et al. Relation of plasma brain natriuretic peptide levels in non-ST-elevation coronary disease and preserved systolic function to number of narrowed coronary arteries. Am J Cardiol 2005; 96: 1705-10.

[142] Neyou A, O'Neill B, Berman A, Boura J, McCullough P. Determinants of markedly elevated BNP levels in patients admitted with ST-Segment elevation myocardial infarction. Eur Heart J 2009 (Submitted).

[143] Malavazos AE, Morricone L, Marocchi A, Ermetici F, Ambrosi B, Corsi MM. N-terminal pro-B-type natriuretic peptide and echocardiographic abnormalities in severely obese patients: correlation with visceral fat. Clin Chem 2006; 52(6): 1211-3.

() McCullough and Ariane Neyou; Licensee Bentham Open.

This is an open access article licensed under the terms of the Creative Commons Attribution Non-Commercial License (http://creativecommons.org/licenses/by-nc/3.0/) which permits unrestricted, non-commercial use, distribution and reproduction in any medium, provided the work is properly cited. 